\title{
Florida Carpon Desmodium ${ }^{1}$
}

\section{B. Adjei and A. E. Kretschmer, Jr. ${ }^{2}$}

Florida carpon desmodium (Figure 1), Desmodium heterocarpon, is among the few perennial summer-growing, grazing-tolerant, herbaceous pasture legumes available to Florida cattle producers. It has creeping to ascending stems that may be more than 40 inches long and become prostrate under heavy grazing. The leaves usually have three leaflets, but leaves with a single leaflet may be found on the lower stems of mature plants and on seedlings. Leaflets are smooth on the upper surface but hairy on the lower surface. They usually have a light green to yellow "watermark" on the leaflets. On a dense flower stalk, pinkish flowers originate from axillary or terminal racemes. Pods are erect or ascending, narrowly oblong, compressed, and have 4 to 8 jointed segments. Pods turn from green to dark brown as they mature. Seed pods adhere to animals and to clothing.

\section{Adaptation}

Carpon desmodium is adapted to extensive areas of most flatwood soils. However, establishment failures may occur on sites susceptible to flooding if flooding occurs during the early seedling stage.

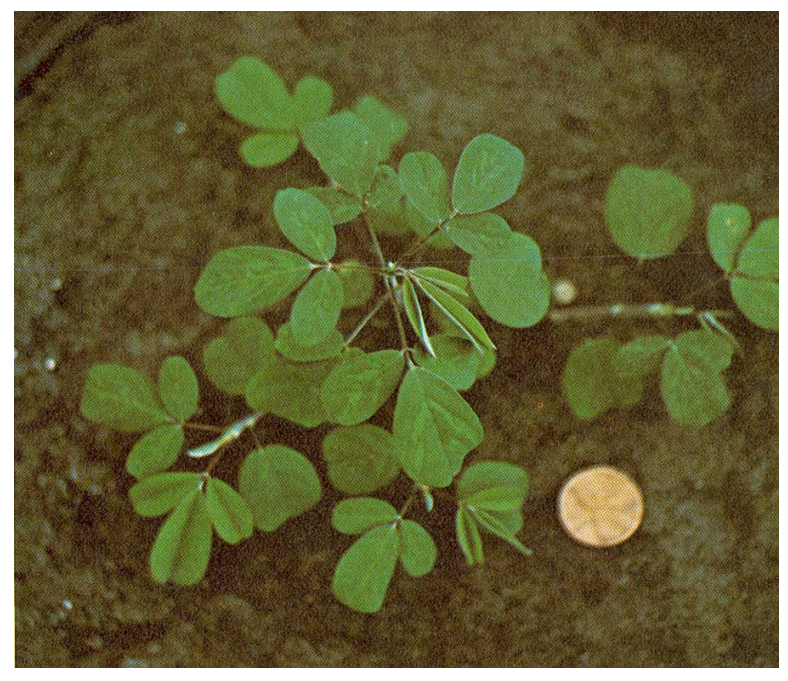

Figure 1. Florida carpon desmodium (Desmodium heterocarpon).

Seedling, but not mature plants are vulnerable to both short term flooding and drought. However, an established field can tolerate excessive moisture and also tolerate a severe spring drought. Approximately $30 \%$ of carpon desmodiums growth in Florida takes place in the spring, $65 \%$ from summer to early fall, and 5\% during the rest of the year. There are an estimated 12,500 acres of pasture established to a

1. This document is SS-AGR-112, one of a series of the Agronomy Department, Florida Cooperative Extension Service, Institute of Food and Agricultural Sciences, University of Florida. Original EDIS publication date February 2006. This publication is also a part of the Florida Forage Handbook, an electronic publication of the Agronomy Department. For more information you may contact M. B. Adjei (mba@ufl.edu). Visit the EDIS Web Site at http://edis.ifas.ufl.edu.

2. M. B. Adjei, associate professor, Agronomy Department, Range Cattle Research and Education Center--Ona, FL; A. E. Kretschmer, Jr., professor emeritus, Agronomy Department; Florida Cooperative Extension Service, Institute of Food and Agricultural Sciences, University of Florida, Gainesville FL 32611. The use of trade names in this publication is solely for the purpose of providing specific information. UF/IFAS does not guarantee or warranty the products named, and references to them in this publication does not signify our approval to the exclusion of other products of suitable composition. 
carpon desmodium and bahiagrass mixture in central and south Florida.

\section{Quality}

The foliage of carpon desmodium contains 12 to $20 \%$ crude protein. Carpon-bahiagrass mixtures have a crude protein concentration of about $10 \%$ and an in-vitro organic matter digestibility of $50 \%$. The legume contributes a high-protein forage to a grass-legume mixture. For example, the annual protein yield of bahiagrass pasture alone, bahiagrass-carpon desmodium mixture, and bahiagrass fertilized with $110 \mathrm{lb} / \mathrm{A}$ of nitrogen can average about 100, 820 (this number appears to be an error to me; how can it be that high with a low-yielding legume), and $370 \mathrm{lb} / \mathrm{A}$, respectively. Carpon desmodium can also add nitrogen to the system. Biologically fixed nitrogen in a moderately grazed mixture with bahiagrass normally ranges from the equivalent of 30 to $75 \mathrm{lb} / \mathrm{A}$ of nitrogen. Nitrogen fixation by carpon desmodium can be negligible if it is continuously heavily grazed or receives nitrogen fertilization. Carpon adds quality to normal bahiagrass production if grazed moderately.

\section{Establishment}

Carpon desmodium seed is very small in size and should not be planted deeper than one-half inch. A cleaned-tilled seedbed is recommended for carpon desmodium establishment. A system of rolling, broadcasting of seed, and re-rolling ensures that seed is not planted deeper than one-half inch. Another consideration of seeding carpon is to plant it when establishing bahiagrass on a clean soil. Where there is an existing grass sod, heavy grazing prior to light disking or chopping should precede the initial rolling, followed again by broadcasting and rolling. A fourth option for establishment is to burn the grass sod in late February, broadcast seed in the ash, followed by light disking and rolling. Seedling growth of carpon desmodium is especially slow; therefore existing grass should be closely grazed throughout the establishment period to enhance legume establishment. Recommended seeding rates are 3 to $5 \mathrm{lb} / \mathrm{A}$ on a clean-tilled seedbed and 5 to $10 \mathrm{lb} / \mathrm{A}$ on established grass sod. In Florida, sowing between March and April may yield early establishment and harvestable seed production in the first year, but with an associated risk of extended periods of drought (April to May) which may result in establishment failure. Sowing in mid- summer increases the chance of rainfall after seed germination, but with an associated risk of greater grass competition and seedling loss from extended flooding. A compromise may be to seed in May or early June. Another potential hazard to establishment of carpon desmodium is susceptibility of seedlings to root-knot nematode, especially following a vegetable crop. On vegetable fields, it is advantageous to make small trial plantings to assess nematode hazards before sowing extensive areas. Cowpea-type inoculum is recommended when sowing on virgin land. In most cases, however, existing microbial populations in Florida flatwood soils provide adequate rhizobia for effective nodulation and nitrogen fixation by carpon desmodium.

\section{Fertilization}

For establishment on virgin soils, about 1 ton/acre of dolomite may be needed to raise the soil $\mathrm{pH}$ to between 5.0 and 6.0. If the soil tests low in phosphorus and potassium, add 0-30-60 lb/A of $\mathrm{N}-\mathrm{P}_{2} \mathrm{O}_{5}-\mathrm{K}_{2} \mathrm{O}$ fertilizer. For old or established fields, soil $\mathrm{pH}$ should be maintained at 5.0 to 6.0 , and again, if the soil tests low in phosphorus and potassium, about $0-30-60 \mathrm{lb} / \mathrm{A}$ of $\mathrm{N}-\mathrm{P}_{2} \mathrm{O}_{5}-\mathrm{K}_{2} \mathrm{O}$ fertilizer should be applied annually. Periodic application of $\mathrm{P}, \mathrm{K}$ and micronutrients containing $\mathrm{S}, \mathrm{Fe}, \mathrm{Cu}, \mathrm{Mn}, \mathrm{Zn}$ and $\mathrm{B}$ is required to maintain long-term productivity of carpon-bahiagrass mixture in Florida.

\section{Management}

When grown as a component of bahiagrass pastures, grass management is critical. Fertilization should include no nitrogen on pastures with good stands of carpon. During spring and early summer, when moisture is limited, bahiagrass regrowth must be heavily grazed to reduce grass competition on the legume. From late summer through the fall, lighter grazing pressure or periods of deferment of grazing (as obtained with a rotational system) is beneficial to carpon desmodium. Since $65 \%$ of the legume growth occurs from late summer through fall, a rest period provides opportunity for the plant to improve vigor, 
support biological nitrogen fixation, and accumulate forage for greater intake of legume by cattle in subsequent grazing periods. A good management technique is to rotationally graze every three to six weeks to allow regrowth to about six inches. Even when seed harvest is not intended, restricting grazing enough to allow some seed to set in the fall is important to maintain stands since individual carpon desmodium plants do not live indefinitely. Managing the two processes of seed set in the fall and summer seedling establishment within a population of perennating plants can help maintain a stable carpon desmodium-bahiagrass plant population over many years, thus improving pasture quality and productivity. The key advantage of carpon desmodium over annual legumes, such as aeschynomene, is individual-plant long-term persistence and tolerance to periodic grazing abuse.

\section{Seed Production}

Management of carpon desmodium for seed is compatible with improved nitrogen fixation. The technique involves reduction in/or deferment of grazing for an extended period beginning in early August until seed is harvested in November. Flowering begins in early September, a concentrated seed set occurs in late October, and seed maturation is completed by mid-November. Mature pods do not shatter readily, but seed from grass-legume mixtures should be harvested when $85-90 \%$ of the pods are mature. Although seed is normally directly combined, windrowing the crop and harvesting with a pickup attachment on the combine can result in seed yields of up to $300 \mathrm{lb} / \mathrm{A}$. 